UDC 94(47).084.2

Submitted: 14.12.2017

LBC 63.3(0).61

Accepted: 25.12.2017

\title{
THE TACTICS OF CONDUCTING COMBAT OPERATIONS OF SOVIET TROOPS DURING THE BATTLE OF STALINGRAD
}

\author{
Vladimir P. Trut \\ Southern Federal University, Rostov-on-Don, Russian Federation
}

\begin{abstract}
The paper deals with both the known and poorly studied aspects of the Stalingrad Battle. The study is based on the analysis of historiography and diverse sources. The author provides the most precise and objective data about the battle and the losses of Soviet troops in the Stalingrad defensive and Stalingrad offensive strategic operations. The documents of the Central Archive of the Ministry of Defense of the Russian Federation have been introduced into scientific circulation for the first time. Their study has allowed analyzing the tactical actions of the Soviet troops in the period of fierce fights in Stalingrad and during the counter-offensive of the Red Army. It's contributed to filling the gaps in the study of the Battle of Stalingrad. Based on these new sources, the paper discusses the nature of military actions of specially formed assault groups of urban combat and their special tactics. These groups played a very important role in the complex conditions of street fighting, particularly during the liberation of the city. During the preparation for the general counter-offensive at the Stalingrad front, the Soviet Command developed a number of new different tactical techniques of the units, which contributed greatly to the success of their offensive operations. Active and large-scale use of the new warfare tactics by the Soviet army in Stalingrad and in the general counter-offensive of the Red Army during the Operation Uranus had let the soldiers successfully perform the military tasks, and inflict defeat. Eventually this played an important role in the victorious end of the Battle of Stalingrad. Using the experience of successful tactics by the Soviet troops during the Battle of Stalingrad played an important role in their subsequent large-scale offensive operations, including the operations in hard conditions of assaults on the cities occupied by the enemy.

Key words: Battle of Stalingrad, Soviet troops, street fighting, counter-offensive, assault groups, new tactics of warfare.

Citation. Trut V.P. The Tactics of Conducting Combat Operations of Soviet Troops during the Battle of Stalingrad. Vestnik Volgogradskogo gosudarstvennogo universiteta. Seriya 4, Istoriya. Regionovedenie. Mezhdunarodnye otnosheniya [Science Journal of Volgograd State University. History. Area Studies. International Relations], 2018, vol. 23, no. 1, pp. 13-25. (in Russian). DOI: https://doi.org/10.15688/jvolsu4.2018.1.2

УДК 94(47).084.2

Дата поступления статьи: 14.12.2017

ББК 63.3(0).61

Дата принятия статьи: 25.12.2017
\end{abstract}

\section{ОСОБЕННОСТИ ТАКТИКИ ВЕДЕНИЯ БОЕВЫХ ДЕЙСТВИЙ СОВЕТСКИХ ВОЙСК В ПЕРИОД СТАЛИНГРАДСКОЙ БИТВЫ}

\author{
Владимир Петрович Трут \\ Южный федеральный университет, г. Ростов-на-Дону, Российская Федерация
}

\begin{abstract}
Аннотация. В статье на основе анализа историографии и разноплановых источников рассматриваются как известные, так и практически неисследованные аспекты Сталинградской битвы. Приводятся наиболее $\infty$ выверенные и объективные данные о ходе сражения и потерях советских войск в Сталинградской оборонительной и Сталинградской наступательной стратегических операциях. Исследование впервые вводимых в научный оборот документов Центрального архива Министерства обороны РФ позволило проанализировать ๓ специфику тактических действий советских войск в период ожесточенных боев в Сталинграде и во время контрнаступления Красной Армии, восполнить имеющиеся пробелы в изучении Сталинградской битвы. На основе этих новых источников рассматриваются состав и тактика боевых действий специально созданных (2) штурмовых групп городского боя и выработанные ими особые тактические приемы. Данные группы сыгра-
\end{abstract}




\section{СТАЛИНГРАДСКИЙ ФРОНТ}

ли очень важную роль в сложных условиях ведения уличных боев, особенно в период освобождения города. При подготовке общего контрнаступления на фронте под Сталинградом советское командование разработало целый ряд новых различных приемов тактических действий частей и соединений, призванных в значительной степени способствовать успеху их наступательных действий. Активное и весьма масштабное использование частями советской армии новой тактики ведения военных действий в Сталинграде и в период общего контрнаступления Красной Армии во время операции «Уран» позволило успешно выполнить поставленные задачи, нанести противнику поражение и, в конечном итоге, сыграло немаловажную роль в победоносном завершении Сталинградской битвы. Использование опыта успешных тактических действий советских войск в ходе Сталинградской битвы сыграло важную роль в их последующих широкомасштабных наступательных действиях, в том числе и в сложных условиях штурмов занятых противником городов.

Ключевые слова: Сталинградская битва, советские войска, уличные бои, контрнаступление, штурмовые группы, новая тактика ведения боевых действий.

Цитирование. Трут В. П. Особенности тактики ведения боевых действий советских войск в период Сталинградской битвы // Вестник Волгоградского государственного университета. Серия 4, История. Регионоведение. Международные отношения. - 2018. - Т. 23, № 1. - C. 13-25. - DOI: https://doi.org/10.15688/ jvolsu4.2018.1.2

Сталинградская битва стала важнейшим рубежным событием Великой Отечественной и Второй мировой войны. Показателем важности исследования различных аспектов Сталинградской битвы и ее значимости для дальнейшего всестороннего и обстоятельного изучения истории Великой Отечественной и всей Второй мировой войн является большое количество специальных исторических исследований, посвященных рассмотрению проблематики данного сражения. Однако, несмотря на их значительное число и весьма широкий спектр изученных вопросов, вплоть до настоящего времени некоторые аспекты Сталинградской битвы остаются слабо исследованными. Так, например, вопросы выработки и применения советскими войсками новых тактических приемов боевых действий в условиях длительных и очень напряженных уличных боев в Сталинграде, особенно в период контрнаступления Красной Армии, применения советскими частями и подразделениями новой тактики во время наступательной операции «Уран» не получили необходимого освещения в работах исследователей. Они, к сожалению, не рассмотрены даже в фундаментальных работах А.М. Самсонова [18], современных обобщающих исследованиях [1-4; 19; $22 ; 23]$, работах последнего времени [7; 8; 16].

Это же можно сказать и о работах зарубежных исследователей. Анализ зарубежной историографии Сталинградской битвы, проведенный в свое время В.К. Печоркиным [16], а на современном этапе А.А. Падериным [15], показал, что основное внимание в ней уделе- но общему анализу хода Сталинградской битвы, действиям немецкого командования, его просчетам. Исключение, пожалуй, составили только работы известного английского военного историка Б.Г. Лиддел-Гарта, отметившего стойкость и удивительную выдержку советских солдат во время битвы [9], и немецкого исследователя Бернда Ульриха, попытавшегося всесторонне и достаточно объективно рассмотреть напряжение и ожесточенность сталинградских боев, стойкость противников, их морально-психологический настрой, а также последствия битвы [32].

В современных исследованиях немецких и американских авторов (в вышедших буквально в последние годы книгах «Сталинград: Город, победивший Третий рейх» под редакцией Йохен Хеллбека [31], Рейнхольда Буша «Выжившие в Сталинграде: свидетельства очевидцев из 6-й армии» [29], Вольфрама Ветте и Герда Уэбершара «Сталинград. Миф и Реальность битв» (обобщающая работа) [33]) круг рассматриваемых вопросов заметно расширен. Заметным событием в историографии Сталинградской битвы стал выход в 2017 г. обобщающего труда известных американских историков Дэвида Гланца и Джонатана Хауса «Сталинград (Современные военные исследования)» [30]. Несмотря на то, что данная работа создана на основе известного пятитомника этих авторов о Второй мировой войне, вышедшего в 2009-2014 гг, она вызвала значительный резонанс среди исследователей. Написанная на большом количестве разнообразного источникового и историографическо- 
го материала книга содержит и очень важные авторские выводы о значении Сталинградской битвы для исхода всей войны. Помимо этого, данная работа практически впервые в историографии включает в себя и анализ некоторых аспектов оперативного уровня, рассмотрение уличных боев в Сталинграде и использовавшиеся при этом противоборствующими сторонами тактические приемы.

Заметным событием научной жизни, посвященным рассмотрению многих аспектов Сталинградской битвы стало проведение в нынешнем году целого ряда представительных международных научных конференций, посвященных обсуждению данной битвы и ее военно-политического и исторического значения. Так, Российское военно-историческое общество, Министерство обороны России, Министерство культуры РФ провели Международную научно-практическую конференцию «Сталинградская битва. К 75-летию контрнаступления советских войск под Сталинградом». На конференции обсуждалось значение Сталинградской битвы в истории Великой Отечественной и Второй мировой войн, и, что примечательно, особое внимание докладчики уделили вопросам ведения боевых действий, их всестороннего обеспечения, военному искусству, полководцам, героям, проблемам плена [21].

Значительный интерес представляют и доклады прошедшей в три этапа в итальянском городе Модена, в Москве и в Воронеже Международной научной конференции «Сражения в России: Дон и Сталинград. Взгляд через 75 лет». Особое внимание на конференции было уделено применению опыта советских полководцев в оперативной и боевой подготовке современных войск, мерам по противодействию фактам фальсификации истории [19].

Несмотря на достаточно обстоятельное и весьма всестороннее изучение событий Сталинградской битвы, вплоть до настоящего времени некоторые аспекты этого важного сражения остаются неисследованными. Вовлечение в научный оборот новых источников по данной проблематике связано с насущной необходимостью дальнейшего глубокого и всестороннего изучения одного из важнейших событий Великой Отечественной и Второй мировой войны.
Слово «Сталинград» стало знаковым, нарицательным, обозначающим колоссальный разгром мощнейшей армии. В то же самое время, во многом вопреки распространенному мнению, Сталинградская битва не являлась самым большим сражением Великой Отечественной и Второй мировой войны: по численности участвовавших войск и боевой техники она меньше Курской битвы, по протяженности линии фронта она скромнее Московской, а по продолжительности она намного короче битвы за Кавказ. Однако Сталинградская битва по праву считается самым ожесточенным и кровопролитным сражением войны. По своему значению эта битва стоит в самом первом ряду решающих сражений Великой Отечественной и Второй мировой войны.

Сталинградская битва включала в себя Сталинградскую стратегическую оборонительную и Сталинградскую стратегическую наступательную операции.

Сталинградская стратегическая оборонительная операция (17 июля - 18 ноября 1942 г.) проводилась войсками Сталинградского (Донского), Юго-Восточного (Сталинградского) фронтов при содействии Волжской военной флотилии. В период этой операции советские войска вели очень напряженные и ожесточенные оборонительные сражения на дальних подступах к Сталинграду, на его ближних подступах и затем непосредственно в самом городе. Она продолжалась 125 суток на ширине фронта боевых действий порядка 250-520 км при глубине отхода Красной Армии на 150 км. За время данной операции советские войска потеряли 643842 тысячи солдат и офицеров, в том числе 323856 убитыми и умершими от ран и 319986 раненными. В результате Сталинградской стратегической оборонительной операции была подорвана наступательная мощь противника, обескровлена его главная ударная группировка на южном крыле советско-германского фронта [17, с. 279].

Сталинградская стратегическая наступательная операция (19 ноября 1942 г. - 2 февраля 1943 г.) осуществлялась войсками ЮгоЗападного, Донского и Сталинградского фронтов при поддержке Волжской военной флотилии. В ее рамках советскими войсками были проведены Ноябрьская фронтовая наступательная операция «Уран» по окружению не- 


\section{СТАЛИНГРАДСКИЙ ФРОНТ}

мецких войск и их союзников под Сталинградом, Котельниковская фронтовая наступательная операция, Среднедонская фронтовая наступательная операция «Малый Сатурн», фронтовая наступательная операция «Кольцо» по ликвидации окруженной в Сталинграде немецкой группировки. Операция проходила в течение 76 суток на фронте шириной 850 км при глубине продвижения советских войск на 150-200 км. За время этой операции Красная Армия потеряла 485777 человек, в том числе 154885 убитыми и 330892 раненными. Итогом этой крупномасштабной военной операции стало окружение и уничтожение главных сил 4-й танковой и 6-й полевой немецких армий, разгром 3-й и 4-й румынских армий, 8-й итальянской армии [17, с. 281].

Потери противника в Сталинградской битве составили порядка 1,5 млн человек, при этом в период советского контрнаступления они превысили 800000 человек [11, с. 387]. По свидетельству известного немецкого исследователя К. Типпельскирха, германские потери в ходе битвы составили около 50 дивизий, при этом, по его словам, непосредственно в Сталинграде «капитулировали шесть пехотных $(44,71,76$, 79, 94-я и 100-я егерская дивизии), три моторизованные (3, 29, 60-я), три танковые дивизии (14, 16 и 24-я), 9-я зенитная артиллерийская дивизия, 1-я кавалерийская и 20-я пехотная румынские дивизии, наконец, хорватский полк, которые в день окружения насчитывали в общей сложности 265 тыс. человек. Из них 90 тыс. попали в плен» [27].

Только в ходе ликвидации окруженных соединений в период с 10 января по 2 февраля было пленено более 91000 солдат и офицеров, включая 2500 офицеров и 24 генерала. И самое главное - победа в Сталинградском сражении стала началом коренного перелома в войне. Красная Армия не только уничтожила одну из самых лучших ударных группировок противника, но и захватила стратегическую инициативу, которую удерживала до окончания войны [17, с. 281-282].

Как справедливо отмечал генерал Вальтер Варлимонт, в Сталинградской битве впервые были разбиты лучшие силы немцев. 6-я армия вышла невредимой из кампании 1941 г., без потерь пережила первую зиму на Восточном фронте, и, по словам генерала Карла-
Адольфа Холлидта, состояла из смелых солдат и храбрых офицеров, имевших за плечами огромный опыт, и была ведома талантливыми, мужественными и амбициозными командирами - но при этом потерпела сокрушительное поражение [10]. По верному замечанию В. Максакова, Сталинград должен был стать для немцев единственным поражением такого масштаба. С этой целью для придания этой битве символического статуса первый и последний раз в Третьем рейхе был объявлен траур. Но это привело к обратным последствиям [10].

По словам К. Типпельскирха, шок от произошедшего усилило осознание того, что уже второй год подряд немцы наносили тяжелые поражения советской армии - но только для того, чтобы она вновь восстала из небытия и, в свою очередь, уничтожила лучшие части вермахта [27].

Сталинградская битва не только продемонстрировала многочисленные и показательные образцы массового героизма, отваги, мужества советских воинов, их поистине несгибаемый боевой дух, но и в очень значительной мере обогатила боевое искусство советских командиров и бойцов, привнесла много нового и важного в стратегию и тактику военных действий Красной Армии. Она повлияла даже на ускорение ее структурной и качественной реорганизации. Последующее изучение и обобщение всех аспектов этой битвы, уникального опыта защитников Сталинграда привело, например, к значительному улучшению, причем на качественно более высоком уровне, взаимодействия различных родов войск советской армии, появлению в ней особых штурмовых групп городского боя, которые впервые были созданы именно в частях, оборонявших Сталинград. Бесценным стал и опыт снайперской и контрснайперской борьбы в городских условиях. Более того, по итогам анализа боевого использования войск во время этой битвы выявились и затем обобщились и внедрялись в частях и подразделениях Красной Армии и весьма специфические аспекты, например, как ни парадоксально это может показаться на первый взгляд, использование во время боев за Сталинград кавалерийских частей. И дело заключалось не только в довольно ограниченном количестве 
мотомеханизированных частей в Красной Армии в то время. Советские кавалерийские подразделения сыграли достаточно значительную роль, поскольку кавалерия легко преодолевала не только открытую, но и сильно овражистую местность, многочисленные балки и заходила в тылы и во фланги неприятельских войск. Оценив боевые возможности кавалерии в тех условиях, советское командование активно и весьма успешно ее использовало. Подтверждением большого внимания к кавалерии служило наращивание, по мере сил и возможностей, ее группировки, несмотря на то, что в сутки на содержание одной лошади требовалось 4 кг овса и 5 кг сена, а в одном только кавалерийском полку по штату числилось порядка 2,5 тыс. лошадей, и, соответственно, требовалось очень большое количество транспортных средств для подвоза фуража. И это при том, что во время данного сражения на счету были каждая единица транспорта, включая гужевого, даже верблюдов. Характерно, что противник также активно использовал в ходе боевых действий под Сталинградом имевшиеся у него кавалерийские соединения, в частности, немецкую и румынскую кавалерийские дивизии.

Анализ битвы повлиял также и на такие специфические вопросы, как ускорение реорганизации системы и номенклатуры снабжения советских войск в целом, отдельных частей и подразделений в частности. Он оказал непосредственное влияние даже на обеспечение советских солдат современным оснащением и обмундированием, поскольку проведенное сравнение их отечественных и неприятельских образцов оказалось явно не в нашу пользу и поставило на повестку дня преобразования в данной области. Все эти необходимые изменения начали осуществляться после Сталинградской битвы.

Подготовка масштабной наступательной операции Красной Армии под Сталинградом требовала поистине колоссальной разноплановой подготовительной работы. Особенное внимание уделялось максимальной скрытности подготовки данной операции. Так, Ставка Верховного Главнокомандования еще в октябре 1942 г. приказывала руководству Сталинградского фронта категорически прекратить пересылку любой информации о планах контрнас- тупательной операции даже шифрованными сообщениями по радиосвязи. С этого времени все относящиеся к данной операции сведения следовало переправлять в виде особых донесений с рукописным текстом, используя специальных связных-посыльных. Особенно строго был поставлен вопрос об отдаче приказов о перегруппировках войск и их подготовке к наступлению: отныне их следовало отдавать только в устной форме лично командующим армиями по карте [5, л. 265].

Необходимо отметить, что при подготовке операции «Уран» советское командование разработало целый ряд новых различных приемов тактических действий частей и соединений, призванных в значительной степени способствовать успеху их наступательных действий. Они вобрали в себя не только богатый и разнообразный боевой опыт советских войск, накопленный в предшествующий период войны, но и обобщение и анализ успешных наступательных действий противника. Примером может служить директива командованию 21-й армии Юго-Западного фронта, в которой ее частям в начале наступления ставилась задача дезорганизовать систему управления противника, захватить его командные пункты, штабы и разрушить линии связи. Для создания пробок и засад на путях подвоза и эвакуации требовалось заблаговременно подготовить активные боевые группы, которым следовало проникать в тыл боевого порядка противника в ходе боя. При первой возможности такие группы должны были пересесть на автотранспорт. В подвижных войсках при развитии наступления в глубине нужно было широко применять выброску на большое удаление от главных сил мелких подвижных подразделений для создания паники в тылах противника. Мобильные наступающие части должны были стремиться к уничтожению авиации противника на аэродромах [13, л. 5-11].

В период подготовки к наступлению приказывалось проводить особые практические занятия с командирами и подразделениями, предназначенными для действия в тылу противника [13, л. 11].

Перед началом контрнаступления советских войск под Сталинградом 62, 64, 51 и 57-я армии удерживали свои позиции от поселка Рынок, плацдармы в Сталинграде и линию фрон- 


\section{СТАЛИНГРАДСКИЙ ФРОНТ}

та южнее Сталинграда. Положение значительно осложнялось таким важным обстоятельством, что на некоторых важных направлениях в полосе Сталинградского фронта противник имел очень существенное преимущество над советскими войсками в живой силе, стрелковом вооружении, и особенно в бронетехнике и авиации. Так, в начале ноября 1942 г. в полосе обороны 62-й армии немецкие войска в 11 раз превосходили по численности танков советские танковые части. В такой ситуации 62-я армия могла только сковывать противника на своем фронте, удерживая свою линию обороны. В полосе обороны 64-й армии противник располагал пятикратным превосходством в количестве танков. Правда, находившиеся на левом фланге Сталинградского фронта 51-я и 57-я армии, имели необходимые силы и средства для наступления и прорыва обороны противостоящих румынских войск. Советское командование предполагало, что немцы для закрытия этих прорывов могли перегруппировать часть своих сил с фронта 62-й армии. Для того чтобы не допустить этой перегруппировки противника, 62-я армия должна была выделить часть своих сил для участия в наступлении. В связи с тем, что перед 51-й и 57-й армиями стояли румынские части, уступавшие в боевой эффективности немецким войскам, командование фронта рассчитывало на успех наступления именно этих двух армий [12, л. 1-3, 9].

Поддержку ударным группировкам 51-й и 57-й армий при прорыве вражеской обороны в ноябрьском наступлении и развитие общего успеха на Сталинградском фронте обеспечивали 13-й и 4-й механизированные корпуса. Благодаря штатному наличию автотранспорта в 4-м механизированном корпусе своевременно проводилось обеспечение и оснащение частей и подразделений корпуса всем необходимым для наступления. Это обеспечило корпусу более глубокое вклинение в оборону противника в первые дни операции «Уран». При этом общая нехватка танков непосредственной поддержки пехоты заставила командира корпуса генерала В.Т. Вольского выделить 158-й и 55-й отдельные танковые полки для поддержки стрелковых соединений 51-й армии [12, л. 42-43].
Большую помощь советским войскам под Сталинградом оказывали инженерные части. Используя понтоны и мелкие металлические баржи, буксируемые катерами, небольшие катера, военнослужащие этих частей только в период с 1 по 20 ноября 1942 г. переправили на западный берег Волги 111476 солдат и офицеров, 427 танков, 556 орудий, 2982 автомашины, 136 тракторов, 7903 лошади, 65616 т боеприпасов, 3759 т продфуража [12, л. 44].

Успешному прорыву обороны противника способствовала саперно-инженерная разведка, проведенная саперами частей и соединений первого эшелона наступающих советских частей. Она в основном правильно вскрыла систему немецко-румынской обороны на направлениях главных ударов. Так, накануне советского наступления перед 57-й армией в районе Тундутово саперной разведкой было выявлено 70 оборонительных сооружений из 95 обнаруженных после захвата рубежа, а в полосе 51-й армии были точно установлены контуры всех минных полей противника [12, л. 44-46].

Специальные инструкции готовившимся к наступлению советским частям обобщали тактику наступательных действий противника в боях летом и осенью 1942 г. под Сталинградом. В них отмечалось, что наступательным действиям вермахта, как правило, предшествовала тщательно организованная разведка. В ходе разведки боем немцами нащупывались стыки и фланги советских частей. В ночное время мелкие группы автоматчиков противника стремились просочиться в расположение советских частей и подразделений. Если это им удавалось, то с наступлением рассвета и началом действия разведгрупп противника с фронта, автоматчики на флангах и в тылу наших войск активизировали свои действия и своим огнем стремились создать видимость окружения. Разведка боем проводилась одновременно в нескольких направлениях под прикрытием танков, огня артиллерии, минометов и даже авиации. Действия разведки сопровождались световыми эффектами, усилением передвижений в глубине боевых порядков немцев для создания впечатления начала большого наступления [26, л. 51-52]. Для подавления огневых точек на 
переднем крае советской обороны противником применялись танки и самоходные артиллерийские установки, которые вели огонь изза укрытий с дистанции не ближе 500-600 м [26, л. 53].

Наступление советских фронтов под Сталинградом, начатое 19 ноября 1942 г., стало началом полного разгрома немецкой группировки между Доном и Волгой. Ударная группировка Сталинградского фронта перешла в наступление 20 ноября 1942 г. на важный рубеж немецкой обороны Ивановка - оз. Барманцак и была нацелена в направлении города Калач. Первый итог операции «Уран» был отмечен 23 ноября 1942 года. В этот день войска Сталинградского фронта, при поддержке армий Донского фронта, встретились у хут. Советский, в районе г. Калач, с соединениями ЮгоЗападного фронта. Тем самым было завершено полное окружение Сталинградской группировки противника. В полосе наступления 51-й и 57-й армий Сталинградского фронта были разбиты 29-я немецкая моторизованная дивизия, 1, 2 и 18-я румынские пехотные дивизии. Территория Сталинградского котла не позволяла простреливать ее насквозь даже дальнобойной артиллерией. В кольце окружения оказалось не менее 250 тыс. человек. Однако план операции до конца не был выполнен, наступающие советские войска не смогли сразу разрезать окруженную группировку на две части и уничтожить 6-ю армию Паулюса [25, с. 168].

Необходимо обратить внимание и на такую отличительную особенность Сталинградской битвы, как длительное ведения масштабных и ожесточенных боевых действий в условиях плотной городской застройки. Как известно, особенно напряженными бои шли непосредственно на улицах Сталинграда. Причем после крупномасштабной и интенсивной вражеской бомбардировки города, особенно после поистине варварского налета немецкой авиации 24 августа 1942 г., приведшей к огромным жертвам среди мирного населения и разрушениям, большая часть города превратилась в руины. Ведение боевых действий в таких условиях требовало использования особой тактики ближнего боя и штурма оборонительных укреплений противника.

Части 6-й немецкой армии за три месяца нахождения в Сталинграде создали здесь сплошную линию обороны, организовали телефонную и радиосвязь, систему инженерных сооружений и минных полей, прикрытых системой огневого воздействия своими орудиями и минометами. Подвалы и каменные здания оборудовались немцами как доты и дзоты. В стенах устраивались амбразуры. На верхних этажах были установлены минометы для стрельбы через окна или крышу. Многие здания были приспособлены для круговой обороны. Вокруг зданий на расстоянии 5060 м противник оборудовал блиндажи с перекрытиями и ходами сообщения. Живая сила противника располагалась в блиндажах впереди домов. При наступлении советских частей немцы последовательно обороняли в первую очередь устроенные впереди блиндажи, а затем здание и после этого переходили по ходам сообщения в блиндажи позади дома [26, л. 53-54].

Основу новой тактики боевых действий советских частей в Сталинградской битве в условиях городского боя составили действия специально создаваемых мобильных отдельных боевых групп. Они получили название штурмовых групп городского боя. Примечательно, что впервые такие группы в Красной Армии были созданы именно в сражавшихся в Сталинграде частях советской армии. Данные группы сыграли важную роль в сражении за город, хорошо проявили себя как при обороне, так и (особенно) при контрнаступлении советских войск непосредственно в Сталинграде.

Учитывая значительный позитивный вклад, который внесли данные группы в боях по освобождению Сталинграда, их эффективную военную тактику при освобождении большого города, буквально сразу же после окончания Сталинградской битвы их боевой опыт был проанализирован, обобщен и рекомендован к применению во всех частях Красной Армии.

В Центральном архиве Министерства обороны РФ находится аналитическая записка, подготовленная в марте 1943 г. старшим помощником начальника Оперативного отдела Центрального фронта ${ }^{1}$ подполковником Оробинским, завизированная начальником Общей части ВКО Генштаба Красной Армии майором Морозовым, под названием «Описание боевых действий штурмовых групп город- 


\section{СТАЛИНГРАДСКИЙ ФРОНТ}

ского боя по опыту действий частей 62-й армии в г. Сталинграде с 1 декабря 1942 г. по 31 января 1943 г.» [14]. В ней отмечалось, что «опыт боевых действий частей нашего фронта в большом городе внес много новых вопросов во вклад военного искусства. Бой в большом городе по-иному определяет тактические действия частей, в особенности мелких подразделений... Природа городского боя определяет характер такой штурмовой группы. Городской бой - это близкий бой: городская атака - это штурм укрепленных домов, зданий и других объектов, превращенных противником в огневые точки, опорные точки и узлы сопротивления. В таких случаях исключается возможность наступательных действий больших подразделений, ведущихся в обычных полевых условиях, поэтому на арену выходит мелкая группа пехоты. Такая группа позволяет шаг за шагом отвоевывать у противника отдельные здания, кварталы - т. е. ликвидировать огневые точки, опорные пункты, узлы сопротивления. Выводы: в городе штурмует мелкая группа... Штурмовая группа явилась в условиях Сталинграда главным звеном городского наступательного боя» $[14$, л. 1-2]. Далее характеризовались состав и структура штурмовых групп и отмечалось, что они состояли из штурмующей группы, группы закрепления и резерва, «подчиненные одной задаче, эти три составные части и образуют штурмовую группу» [14, л. 3]. Вопрос о количестве бойцов в штурмовой группе не являлся принципиальным, его решал командир группы в процессе подготовки к штурму, исходя из данных разведки об огневых средствах, системе огня и силы гарнизона противника. Обязательным условием являлось четкое распределение функций всех составных элементов штурмовой группы: основу всей штурмовой группы составляла штурмующая группа, состоявшая всего лишь из 6-8 человек, которая первой с разных сторон врывалась в дом или другое здание, причем каждая такая группа захватывала четко определенную часть здания по заранее согласованному плану; затем в дело вступала группа закрепления, также состоявшая из нескольких групп, врывавшихся в штурмуемый объект с разных направлений, занимала огневые позиции-точки, создавала новые, образовывала свою сис- тему обороны и препятствовала нанесению противником контрудара извне по захваченному зданию. В отличие от штурмующих групп, имевших только легкое вооружение в виде автоматов, гранат, ножей, лопат, группы закрепления располагали также тяжелым стрелковым вооружением (станковыми и ручными пулеметами, противотанковыми ружьями, минометами, по возможности даже противотанковыми орудиями), ломами, кирками, взрывчаткой. В их состав входили, помимо стрелков, саперы и снайперы. Резерв использовался для пополнения штурмующих групп, для пресечения возможных контратак противника с флангов, а при необходимости и как блокирующая группа. Каждая их этих групп имела своего командира, которые, в свою очередь, подчинялись командиру общей штурмовой группы [14, л. 2-3]. А далее в аналитической записке следовал очень важный вывод о том, что в подразделениях не должно было быть особых штатных штурмовых групп, каждый боец того или иного стрелкового подразделения должен был уметь штурмовать занятые и укрепленные врагом объекты. Отделение, взвод, рота должны были осваивать штурмовые действия также, как любой другой маневр пехоты. Важным считалось то обстоятельства, чтобы штурмовые группы формировались из состава одного и того же подразделения, из одной части, чтобы бойцы и командиры хорошо знали друг друга [14, л. 3]. В основе маневра штурмовых групп должны были лежать два главных фактора - короткое время захвата объекта и внезапность штурма. При этом сам штурм должен быть «подготовлен строжайше и рассчитан точно» $[14$, л. 4$]$. В основе подготовки штурма лежали два момента : изучение объекта штурма и разработка его плана. При выработке плана штурма командир штурмовой группы должен предусмотреть решение таких главных вопросов, как определение состава и боевого порядка штурмующих групп, состав групп закрепления, размер резерва, задачи групп на разных этапах боя, степень поддержки атаки огневыми средствами из глубины, согласование сигналов и обеспечение связью $[14$, л. 5$]$.

Особое внимание уделялось и характеристике тактики действий штурмовой группы. 
Эта тактика должна была быть гибкой, отвечать быстроте натиска, включать в себя инициативу и большую дерзость каждого бойца, который в условиях тесноты помещений и их неизвестности должен постоянно успевать реагировать на возникавшие опасности и быть максимально внимательным и мобильным: «успевай и поворачивайся, будь готов к неожиданностям, не бойся, не медли». Предусматривалось активное использование гранат, а в рукопашном бою - ножей и лопат $[14$, л. 6$]$. Обращалось внимание и на важные вопросы выработки взаимодействия штурмовых групп с находившейся в тылу артиллерией, обеспечения последней поддержки действий этих групп, особенно при начале штурма и при возможных контратаках противника; использования при штурме ночного времени суток и дымовых завес, подземно-минных атак, активных действий саперов $[14$, л. 7-8]; а также воспитания у каждого бойца качеств инициативы и дерзости действий, кропотливой работы с необходимым обучением пополнений [14, л. 8-9].

Во время боев в Сталинграде советские войска вырабатывали и новые тактические приемы при штурме очень хорошо укрепленных господствующих высот. Одной из главных командных высот, занятых противником, была знаменитая высота 102.0, известная как Мамаев курган. Мамаев курган был оборудован узлами сопротивления, долговременными и скрытыми огневыми точками. Передний край обороны был насыщен ручными и станковыми пулеметами, что создавало высокую плотность стрелкового огня. Чтобы уцелеть в результате артиллерийско-минометного огня советских орудий, немецкие дзоты были достаточно многослойно перекрыты. Противник имел тактическую выгоду - благодаря возвышенности местность просматривалась на несколько километров [28, л. 285].

На примере боевых действий 284-й стрелковой дивизии 62-й армии в середине декабря 1942 г. командованием впоследствии были проанализированы успешные и неудачные тактические действия советских частей при штурме хорошо укрепленной высоты, сделаны соответствующие выводы и разработаны рекомендации войскам на будущее. В задачи 284-й дивизии входило овладение высо- той 102.0 в ночное время суток, внезапно, без предварительной артиллерийской поддержки. Были созданы две пехотные группы численностью до 125 человек каждая, чтобы первая группа атаковала, захватила высоту штурмом, а вторая провела закрепление на достигнутых позициях. Огневыми средствами усиления для подавления немецких амбразур на Мамаевом кургане с наступающими группами выступали легкие артиллерийские орудия калибров 4576 мм. Однако при выходе пехотинцев на исходные позиции образовалась скученность бойцов на узком пятачке в овраге. Поднятый при этом шум привлек внимание противника, который ту же открыл пулеметный огонь, что сразу же сорвало скрытность готовившейся атаки. Многие командиры батальонов не знали точного расположения огневых средств противника, что привело к неправильному управлению приданной артиллерией. Во время атаки один батальон смог выйти к первым траншеям противника на высоте через непростреливаемый участок, а еще два батальона встретили сильный фланговый огонь и не смогли продвинуться. Первый батальон, вышедший на высоту, вел гранатный огонь и смог отбить немецкую контратаку, но, понеся большие потери, вынужден был отойти [28, л. 286-287].

Причинами неудачной атаки было отсутствие организованного подноса боеприпасов: вышедший к высоте батальон не смог задержать противника гранатами в связи с их минимальным запасом. При этом пулеметчики не успевали за наступающей пехотой, что в конечном итоге привело к большим потерям и оставлению захваченных позиций противника. Бои за высоту 102.0 длились 135 дней, окончательно Мамаевым курганом 62-я армия овладела только 25 января 1943 г. на завершающей стадии операции «Кольцо» [28, л. 287]. Примечательно, что эти неудачные действия буквально сразу же стали предметом анализа советского командования, стремившегося извлечь из них соответствующие уроки. В результате были сделаны правильные выводы, содержание которых было вскоре доведено до командиров частей с целью недопущения аналогичных ошибок в будущем. Бои в Сталинграде стали очень суровой и важной школой для советских войск. Школой роста боевого 


\section{СТАЛИНГРАДСКИЙ ФРОНТ}

мастерства, совершенствования военной тактики, причем тактики наступательных действий, что оказалось крайне востребованным в последующих наступлениях Красной Армии.

Таким образом, именно во время Сталинградской битвы в советских частях и подразделениях были разработаны новые, очень эффективные тактические приемы ведения военных действий в сложных условиях уличных боев в городе. Специально создаваемые группы городского боя, выработанные ими особые тактические приемы сыграли важную роль в напряженных уличных боях, особенно во время освобождения города.

При подготовке общего контрнаступления на фронте под Сталинградом советское командование разработало целый ряд новых различных приемов тактических действий частей и соединений, призванных в значительной степени способствовать успеху их наступательных действий. Они вобрали в себя не только богатый и разнообразный боевой опыт советских войск, накопленный в предшествующий период войны, но и обобщение, и анализ успешных наступательных действий противника. В ходе контрнаступления Красной Армии во время операции «Уран» это в значительной мере способствовало победным действиям советских частей.

Активное использование частями советской армии новых тактических приемов ведения боевых действий в Сталинграде и в период общего контрнаступления Красной Армии позволило выполнить поставленные задачи, нанести противнику поражение и, в конечном итоге, сыграло немаловажную роль в победоносном завершении Сталинградской битвы. Более того, разработанные в период битвы новые тактические приемы ведения наступательных боевых действий, особенно в условиях уличных боев в городах, успешно применялись на последующих этапах войны, когда Красной Армии приходилось штурмовать большие города, превращенные противником в крупные оборонительные узлы. При этом обеспечивалось заметное уменьшение боевых потерь и очень существенно сокращалось время занятия того или иного города. Важно отметить и еще одну особенность новых тактических приемов наступательного боя, опробованных в Сталинградской битве, а именно общий подход к подготовке специальных штурмовых групп при широкомасштабном наступлении и особых штурмовых групп городского боя: аналогичные группы существовали и у противника, причем впервые такие группы применили немцы еще в период боев за Верден во время Первой мировой войны, но они состояли из специально подготовленных бойцов, на подбор и обучение которых тратилось немало времени и ресурсов, а в советской армии уже в период Сталинградской битвы пошли по принципиально иному пути - выработанным новым тактическим приемам ведения наступательных боев, в том числе в городских условиях, стали обучать все стрелковые подразделения Красной Армии как одним их обязательных элементов общей тактической подготовки. В дальнейшем это позволило формировать такие группы в период наступления из числа солдат и офицеров обычных стрелковых подразделений. Подготовленные таким образом советские части успешно участвовали в последующих широкомасштабных наступательных действиях, в том числе и в сложных условиях штурмов занятых противником городов. В данном плане опыт Сталинградской битвы оказался поистине бесценным.

Победа советской армии в Сталинградской битве не только стала началом коренного перелома во всей войне, привела не только к уничтожению одной из самых лучших ударных группировок противника, но и к общему переходу стратегической инициативы к Красной Армии, которую она успешно удерживала вплоть до самого окончания войны.

\section{ПРИМЕЧАНИЕ}

${ }^{1}$ Центральный фронт был создан 15 февраля 1943 г. на основе расформированного Донского фронта.

\section{СПИСОК ЛИТЕРАТУРЫ}

1. Великая Отечественная война 19411945 гг. : Военно-исторические очерки. В 4 кн. Кн. 1. Суровые испытания / под ред. Н. М. Раманичева. М. : Наука, 1998. - 544 c.

2. Великая Отечественная война 19411945 гг. : Военно-исторические очерки. В 4 кн. Кн. 2. 
Перелом / под ред. В. И. Фесенко. - М. : Наука, 1998. -512 c.

3. Великая Отечественная война 19411945 гг. : Военно-исторические очерки. В 4 кн. Кн. 3. Освобождение / под ред. В. Н. Петрова. - М. : Наука, 1999. - $510 \mathrm{c}$.

4. Великая Отечественная война 19411945 гг. : Военно-исторические очерки. В 4 кн. Кн. 4. Народ и война / под ред. В. А. Пронько. - М. : Наука, 1999. - 367 с.

5. Директива Ставки ВГК командующему войсками Сталинградского фронта об обеспечении скрытости подготовки наступательной операции от 19.101942 г. // Центральный архив Министерства обороны Российской Федерации (ЦАМО РФ). Ф. 48-a. - Оп. 455. - Д. 3.

6. Исаев, А. В. Неизвестный Сталинград. Как перевирают историю / А. В. Исаев.- М. : Яуза : Эксмо, 2012. - 488 c.

7. Исаев, А. В. Сталинград. За Волгой для нас земли нет / А. В. Исаев.- М. : Яуза : Эксмо, 2008. $448 \mathrm{c}$.

8. Куманев, Г. А. Сталинградская битва : Краткий военно-исторический очерк, документы и материалы / Г. А. Куманев. - М. : Бимпа, 2007. $832 \mathrm{c}$

9. Лиддел-Гарт, Б. Г. Вторая мировая война / Б. Г. Лидделл-Гарт. - М. : АСТ ; СПб. : Terra Fantastica, 2003. $-938 \mathrm{c}$.

10. Максаков, В. «Первый и последний раз в Третьем рейхе объявили траур» / В. Максаков // Газета.ru. - Электрон. текстовые дан. - Режим доступа: https://www.gazeta.ru/comments/2017/11/ 16_a_10988984.shtml (дата обращения: 07.07.2017). Загл. с экрана.

11. Мединский, В. Р. Война. Мифы СССР. 1939-1945. - М. : ОЛМА-Медиа Групп, 2011. -656 с.

12. Ноябрьская операция Сталинградского фронта по окружению немцев под Сталинградом с 20 по 24 ноября 1942 г. // ЦАМО РФ. - Ф. 48. Оп. 451. - Д. 163.

13. Оперативная директива командующего войсками Юго-Западного фронта командующему 21-й армией о подготовке наступательной операции с целью окружения главных сил Сталинградской группировки противника (операция «Уран») от 08.111942 г. // ЦАМО РФ. - Ф. 229. - Оп. 590. - Д. 2.

14. Описание боевых действий штурмовых групп городского боя по опыту боевых действий частей 62-й армии в городе Сталинграде с 1 декабря 1942 г. по 31 января 1943 г. // ЦАМО РФ. Ф. 1202. - Оп. 1. - Д. 12.

15. Падерин, А. А. Сталинградская битва в зеркале западной историографии / А. А.Падерин // Вестник МГИМО Университета. - 2013. - № 2 (29). C. $95-106$.
16. Печоркин, В. К. Новые зарубежные работы о Сталинградской битве / В. К. Печоркин // Вопросы истории. - 1966. - Июль (№ 7). - С. 177-184.

17. Россия и СССР в войнах XX века : Статистическое исследование / под ред. Г. Ф. Кривошеева. -М. : ОЛМА-ПРЕСС, 2001.-608 с.

18. Самсонов, А. М. Сталинградская битва / А. М. Самсонов. - 4-е изд., испр. и доп. - М. : Наука, 1989. - 630 с.

19. Сражения в России: Дон и Сталинград. Взгляд через 75 лет : Междунар. науч. конф. - Электрон. текстовые дан. - Режим доступа: https://rvio. histrf.ru/soobshestvo/post-7565 (дата обращения: 24.09.2017). - Загл. с экрана.

20. Сталинградская битва. Июль 1942 - февраль 1943 г. : Энциклопедия / под ред. М. М. Загорулько. - 2-е изд., испр. и доп. - Волгоград : Издатель, 2010. $-751 \mathrm{c}$.

21. Сталинградская битва : К 75-летию контрнаступления советских войск под Сталинградом : Междунар. науч.-практ. конф. - Электрон. текстовые дан. - Режим доступа: https://rvio.histrf.ru/ activities/news/item-4272 (дата обращения: 16.08.2017). - Загл. с экрана.

22. Сталинградская битва : Хроника, факты, люди. В 2 т. Т. 1 / В. А. Жилин, В. А. Греджев, О. В. Саксонов, В. Ю. Черногор, В. Л. Широков. - М. : ОЛМА-Пресс, 2002. -912 c.

23. Сталинградская битва : Хроника, факты, люди. В 2 т. Т. 2 / В. А. Жилин, В. А. Греджев, О. В. Саксонов, В. Ю. Черногор, В. Л. Широков. - М. : ОЛМАПресс, 2002.-576 c.

24. Сталинградская эпопея. - М. : ЗвонницаМГ, 2012. - $496 \mathrm{c}$.

25. Сталинградская эпопея. - М. : Наука, 1968. $-618 \mathrm{c}$.

26. Тактические приемы борьбы за Сталинград от 21.111942 г. // ЦАМО РФ. - Ф. 1128. - Оп. 1. - Д. 19.

27. Типпельскирх, Курт фон. История Второй мировой войны / Курт фон Типпельскирх. - Электрон. текстовые дан. - Режим доступа: http:/elibra.su/read/144314-istoriya-vtoroj-mirovoj-vojny. html (дата обращения: 17.01.2017). - Загл. с экрана.

28. Тылы дивизии в боях за Сталинград с 27 сентября по 14 ноября 1942 г. // ЦАМО РФ. Ф. 345. - Оп. 5487. - Д. 54.

29. Busch, R. Survivors of Stalingrad: Eyewitness Accounts from the 6th Army, 1942-1943. - London : Frontline Books, 2016. - $256 \mathrm{p}$.

30. Glantz, D. M. House Stalingrad (Modern War Studies) / D. M. Glantz, M. Jonathan. - Kansas : Abridged, 2017. $-640 \mathrm{p}$.

31. Stalingrad: The City that Defeated the Third Reich / hardcover by Jochen Hellbeck (editor) ; Christopher Tauchen (translator). - New York : Public Affairs, 2015. $-512 \mathrm{p}$. 
32. Ulrich, B. Stalingrad / B. Ulrich. - München : Verlag C. H. Beck, 2005. -376 p.

33. Stalingrad: Mythos und Wirklichkeit einer Schlacht / herausgegeben von Wolfram Wette und Gerd R. Ueberschar. - Erweiterte Neuausg. zugleich 5. Aufl. - Frankfurt am Main : Fischer Taschenbuch Verlag, 2012 .-328 S.

\section{REFERENCES}

1. Ramanichev N.M., ed. Velikaya Otechestvennaya voyna 1941-1945 gg. : Voennoistoricheskie ocherki. V 4 kn. Kn. 1. Surovye ispytaniya [The Great Patriotic War of 1941-1945: Military Historical Essays. In 4 Books. Book 1. Hardships]. Moscow, Nauka Publ., 1998. 544 p.

2. Fesenko V.I., ed. Velikaya Otechestvennaya voyna 1941-1945 gg.: Voenno-istoricheskie ocherki. $V 4$ kn. Kn. 2. Perelom [The Great Patriotic War of 19411945: Military Historical Essays. In 4 Books. Book 2. Turning Point]. Moscow, Nauka Publ., 1998. 512 p.

3. Petrov V.N., ed. Velikaya Otechestvennaya voyna 11941-1945 gg.: Voenno-istoricheskie ocherki. V 4 kn. Kn. 3. Osvobozhdenie [The Great Patriotic War of 1941-1945: Military Historical Essays. In 4 Books. Book 3. Emancipation]. Moscow, Nauka Publ., 1999. $510 \mathrm{p}$.

4. Pronko V.A., ed. Velikaya Otechestvennaya voyna 1941-1945 gg.: Voenno-istoricheskie ocherki. $V 4$ kn. Kn. 4. Narod i voyna [The Great Patriotic War of 1941-1945: Military Historical Essays. In 4 Books. Book 4. People and War]. Moscow, Nauka Publ., 1999. 367 p.

5. Direktiva Stavki VGK komanduyushchemu voyskami Stalingradskogo fronta ob obespechenii skrytosti podgotovki nastupatelnoy operatsii ot 19.101942 g. [Directive of the Supreme Headquarters of the Supreme Command to the Commander of the Troops of the Stalingrad Front on Securing the Concealment of the Preparation of the Offensive Operation of October 10, 1942]. Tsentralnyy arkhiv Ministerstva oborony Rossiyskoy Federatsii [Central Archive of the Ministry of Defense of the Russian Federation], F. 48-a, Op. 455, D. 3.

6. Isaev A.V. Neizvestnyy Stalingrad. Kak perevirayut istoriyu [Unknown Stalingrad. How Do They Misinterpret the History]. Moscow, Yauza; Eksmo Publ., 2012. 488 p.

7. Isaev A.V. Stalingrad. Za Volgoy dlya nas zemli net [Stalingrad. There Is No Land Beyond the Volga for Us]. Moscow, Yauza; Eksmo Publ., 2008. 448 p.

8. Kumanev G.A. Stalingradskaya bitva. Kratkiy voenno-istoricheskiy ocherk, dokumenty $i$ materialy [The Battle of Stalingrad. A Brief Military History Essay, Documents and Materials]. Moscow, Bimpa Publ., 2007. 832 p.
9. Liddel-Gart B.G. Vtoraya mirovaya voyna [The Second World War]. Moscow, AST Publ.; Saint Petersburg, Terra Fantastica Publ., 2003. 938 p.

10. Maksakov V. «Pervyy i posledniy raz v Tretyem reykhe obyavili traur» ["The Third Reich Declared Mourning for the First and for Last Time"]. Gazeta.ru. URL: https://www.gazeta.ru/comments/ 2017/11/16 a 10988984.shtml. (accessed July 7, 2017).

11. Medinskiy V.R. Voyna. Mify SSSR. 19391945 [War. Myths of the USSR. 1939-1945]. Moscow, OLMA-Media Grupp Publ., 2011. 656 p.

12. Noyabrskaya operatsiya Stalingradskogo fronta po okruzheniyu nemtsev pod Stalingradom s 20 po 24 noyabrya 1942 g. [November Operation of the Stalingrad Front on the Encirclement of the Germans at Stalingrad from November 20 to 24, 1942]. Tsentralnyy arkhiv Ministerstva oborony Rossiyskoy Federatsii [Central Archive of the Ministry of Defense of the Russian Federation], F. 48, Op. 451, D. 163.

13. Operativnaya direktiva komanduyushchego voyskami Yugo-Zapadnogo fronta komanduyushchemu 21-y armiey o podgotovke nastupatelnoy operatsii s tselyu okruzheniya glavnykh sil Stalingradskoy gruppirovki protivnika (operatsiya «Uran») ot 08.11.1942 g. [Operational Directive of the Commander of the Southwestern Front to the Commander of the Fifth Panzer Army on the Preparation of an Offensive Operation on Encircling the Main Forces of the Stalingrad Enemy Grouping (Uranus Operation)]. Tsentralnyy arkhiv Ministerstva oborony Rossiyskoy Federatsii [Central Archive of the Ministry of Defense of the Russian Federation], F. 229, Op. 590, D. 2.

14. Opisanie boevykh deystviy shturmovykh grupp gorodskogo boya po opytu boevykh deystviy chastey 62-y armii v gorode Stalingrade s 1 dekabrya 1942 g. po 31 yanvarya $1943 \mathrm{~g}$. [Description of the Combat Actions of Assault Groups ofCity Fighting from the Experience of Combat Operations of Units of the $62^{\text {nd }}$ Army in the City of Stalingrad from December 1, 1942 to January 31, 1943]. Tsentralnyy arkhiv Ministerstva oborony Rossiyskoy Federatsii [Central Archive of the Ministry of Defense of the Russian Federation], F. 1202, Op. 1, D. 12.

15. Paderin A.A. Stalingradskaya bitva v zerkale zapadnoy istoriografii [The Stalingrad Battle in the Western Historiography]. Vestnik MGIMO Universiteta, 2013, no. 2 (29), pp. 95-106.

16. Pechorkin V.K. Novye zarubezhnye raboty o Stalingradskoy bitve [New Foreign Works on the Battle of Stalingrad]. Voprosy istorii, 1966, no. 7, pp. 177-184.

17. Krivosheev G.F., ed. Rossiya i SSSR v voynakh XX veka: Statisticheskoe issledovanie [Russia and the USSR in the Wars of the $20^{\text {th }}$ Century. Statistical Study]. Moscow, OLMA-PRESS, 2001. 608 p.

18. Samsonov A.M. Stalingradskaya bitva [The Battle of Stalingrad]. Moscow, 1989. 632 p. 
19. Srazheniya v Rossii: Don i Stalingrad. Vzglyad cherez 75 let: Mezhdunar. nauch. konf. [Battles in Russia: Don and Stalingrad. A Look in 75 Years. International Academic Conference]. URL: https://rvio.histrf.ru/soobshestvo/post-7565. (accessed September 24, 2017).

20. Zagorulko M.M., ed. Stalingradskaya bitva. Iyul 1942 -fevral 1943 g.: Entsiklopediya [The Battle of Stalingrad. July 1942 - February 1943. Encyclopedia]. Volgograd, Izdatel Publ., 2010. 751 p.

21. Stalingradskaya bitva. K 75-letiyu kontrnastupleniya sovetskikh voysk pod Stalingradom: Mezhdunar. nauch.-prakt. konf. [The Battle of Stalingrad. To the $75^{\text {th }}$ Anniversary of Counter-Offensive of Soviet Troops at Stalingrad. International Research and Practice Conference]. URL: https://rvio.histrf.ru/activities/news/ item-4272. (accessed August 16, 2017).

22. Zhilin V.A., Gredzhev V.A., Saksonov O.V., Chernogor V.Yu., Shirokov V.L. Stalingradskaya bitva: Khronika, fakty, lyudi. V 2 t. T. 1 [The Battle of Stalingrad. Chronicle, Facts, People. In 2 Vols. Vol. 1]. Moscow, OLMA-Press, 2002. 912 p.

23. Zhilin V.A., Gredzhev V.A., Saksonov O.V., Chernogor V.Yu., Shirokov V.L. Stalingradskaya bitva: Khronika, fakty, lyudi. V 2 t. T. 2 [The Battle of Stalingrad. Chronicle, Facts, People. In 2 Vols. Vol. 2]. Moscow, OLMA-Press, 2002. $576 \mathrm{p}$.

24. Stalingradskaya epopeya [The Stalingrad Epic]. Moscow, Zvonnitsa-MG Publ., 2012. 496 p.

25. Stalingradskaya epopeya [The Stalingrad Epic]. Moscow, Nauka Publ., 1968. 618 p.
26. Takticheskie priemy borby za Stalingrad ot 21.11.1942 g. [Tactical Techniques of the Struggle for Stalingrad of November 21, 1942]. Tsentralnyy arkhiv Ministerstva oborony Rossiyskoy Federatsii [Central Archive of the Ministry of Defense of the Russian Federation], F. 1128, Op. 1, D. 19.

27. Tippelskirh K. Istoriya Vtoroy mirovoy voyny [The History of World War II]. URL: http://e-libra.su/ read/144314-istoriya-vtoroj-mirovoj-vojny.html. (accessed January 17, 2017).

28. Tyly divizii $\mathrm{v}$ boyakh za Stalingrad s 27 sentyabrya po 14 noyabrya $1942 \mathrm{~g}$. [Rear of the Division in the Fights for Stalingrad from September 27 to November 14, 1942]. Tsentralnyy arkhiv Ministerstva oborony Rossiyskoy Federatsii [Central Archive of the Ministry of Defense of the Russian Federation], F. 345, Op. 5487, D. 54.

29. Busch R. Survivors of Stalingrad: Eyewitness Accounts from the 6th Army, 1942-1943. London, 2016. $256 \mathrm{p}$.

30. Glantz D. M., Jonathan M. House Stalingrad (Modern War Studies). Kansas, Abridged, 2017. $640 \mathrm{p}$.

31. Hellbeck J., ed. Stalingrad: The City that Defeated the Third Reich. Public Affairs, 2015.512 p.

32. Ulrich V. Stalingrad. München, Verlag C. H. Beck, 2005.376 p.

33. Wette W., Gerd R. Ueberschär (Hrsg.): Stalingrad. Mythos und Wirklichkeiteiner Schlacht. Erweiterte Neuauflage, zugleich 5. Auflage. Frankfurt am Main, Fischer, 2012. 454 p.

\section{Information about the Author}

Vladimir P. Trut, Doctor of Sciences (History), Professor, Department of History of Russia of the $20^{\text {th }}-21^{\text {st }}$ cc., Southern Federal University, Bolshaya Sadovaya St., 33, 344007 Rostov-on-Don, Russian Federation, trut.vladimir@rambler.ru, https://orcid.org/0000-0002-2833-629X

\section{Информация об авторе}

Владимир Петрович Трут, профессор, доктор исторических наук, профессор кафедры истории России XX-XXI веков, Южный федеральный университет, ул. Большая Садовая, 33, 344007 г. Ростов-на-Дону, Российская Федерация, trut.vladimir@rambler.ru, https://orcid.org/0000-0002-2833-629X 